\title{
Eco-friendly vermitechnological winery waste management: a pilot-scale study
}

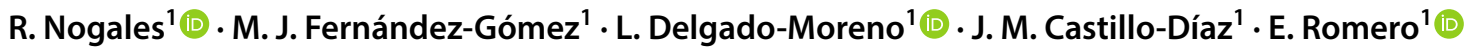

Received: 27 November 2019 / Accepted: 7 March 2020 / Published online: 14 March 2020

(c) Springer Nature Switzerland AG 2020

\begin{abstract}
Enormous quantities of winery wastes are generated in grape-growing regions around the world. The aim of this study was to gather key pilot-scale data on the use of different winery wastes in a vermitechnological system to produce commercially viable soil organic amendments. Exhausted grape marc $(G)$, lees cake mixed with exhausted grape marc (LG), and biosolid vinasse mixed with vine shoots (SV) were tested as substrates for vermicomposting. Changes in earthworm development, enzyme activities, chemical properties, organic matter fractions, and phytotoxicity were assessed along 6 months of vermicomposting and after a subsequent maturation period of 2 months. The organic matter composition of the three produced vermicomposts was also characterized using pyrolysis-gas chromatography (Py-GC). During vermicomposting, earthworm number increased significantly in both LG and SV, with earthworm biomass peaking after 2 months. By contrast, $G$ failed to provide adequate nourishment for earthworms. Dehydrogenase and hydrolytic enzyme activities peaked after 2 months and then declined as available organic compounds diminished. Overall, hydrolytic enzyme activities tended to stabilize during maturation. After vermicomposting and maturation, total organic carbon, soluble carbon, phytotoxicity, electrical conductivity, $C / N$ ratios, and polyphenol content decreased, whereas $\mathrm{pH}$, phosphorus, micronutrients, and humification ratios increased. Using Py-GC, the vermicompost from SV was found to contain the most evolved organic matter in view of its higher degree of humification and lower mineralization index. Nevertheless, all the different winery wastes could be biotransformed, by using vermitechnology, into high value-added soil organic amendments with a degree of stability and maturity adequate to be marketed.
\end{abstract}

Keywords Winery waste $\cdot$ Eisenia fetida $\cdot$ Pilot scale $\cdot$ Enzyme activities $\cdot$ Chemical properties $\cdot$ Pyrolysis-GC

\section{Introduction}

Grapes are among the world's major fruit crops, with more than $60 \times 10^{6}$ tonnes produced annually. In $2017,44.3 \%$ of total wine-growing areas were located in European Union countries, which were responsible for $56 \%$ of wine production worldwide, being Spain, France, and Italy the largest European producers [1]. This intensive wine production entails a large amount of wastes annually produced by viticulture and wine industry activities. In recent years, environmentally friendly technologies have been developed to recycle these organic materials [2]. The main wastes produced by both activities are vine shoots, exhausted grape marc, and lees cake [3]. In addition, the distillation of alcohol from low-quality wines generates large volumes of a highly polluting acidic wastewater called wine vinasse. Wine vinasse is treated through chemical and biological treatments [4], producing a depurated wastewater as well as a wine solid waste called vinasse sludge, in some cases.

Vermitechnology is an environmentally friendly and economically viable process to biotransform and stabilize a variety of organic wastes through the joint action

R. Nogales, rogelio.nogales@eez.csic.es | 'Department of Environmental Protection, Estación Experimental del Zaidín (EEZ-CSIC), C/ Profesor Albareda 1, 18008 Granada, Spain. 
of earthworms and microorganisms under aerobic and mesophilic conditions [5]. Vermitechnology involves two different steps: (1) vermicomposting stage, in which earthworms process organic wastes, modifying their physicochemical properties and their microbial composition, followed by (2) a maturation period, when the earthworms are removed and microorganisms take over the final decomposition and stabilization [6]. Vermitechnology is used to facilitate the stabilization and maturation of a wide variety of anthropogenic organic wastes generated by industries such as sugar refining [7], paper [8], food [9], distilleries [10], beverages [11], tanning [12], and olive-oil milling [13]. Vermitechnology has mainly been studied in relation to small-scale stabilization of grape marc over short periods of time [3, 14], while other wine-making waste, such as lees cake and vinasse sludge, have been scarcely studied [6].

Various physical, chemical, and biochemical (enzyme activities) parameters have been traditionally used to monitor decomposition and stabilization of organic wastes by vermicomposting processes as well as to evaluate agronomic quality of resulting vermicomposts $[5,15-17]$. Regarding quality of organic matter in final vermicomposts, humic substance formation during vermicomposting has been specially studied as indicator of stability and maturity [18]. With that aim, pyrolysis-gas chromatography has been used to characterize organic matter and its humic fractions $[19,20]$. The principal advantage of this technique is that it can be used as a direct chemical probe in soil samples and organic materials without prior extraction, thus avoiding the need to use other sophisticated analytical techniques, such as infrared ultraviolet-visible light, nuclear magnetic resonance spectroscopy, potentiometric titration, oxidative reductive polymeric degradation, gel-column filtration, or electrophoresis.

This pilot-scale study describes a comprehensive and practical examination of the vermicomposting of different winery wastes with the aim of extrapolating the vermicomposting of winery wastes at industrial scale. The effectiveness of vermicomposting winery wastes was assessed by monitoring earthworm growth and reproduction, as well as by analyzing four enzyme activities over the course of a 6-month period of vermicomposting and after a subsequent 2-month period of maturation. Differences in chemical composition, phytotoxicity, and organic matter fractions between initial winery substrates and final mature vermicomposts were also evaluated. Finally, the chemical structural composition of organic matter in mature vermicomposts was also determined by using pyrolysis-gas chromatography.

\section{Materials and methods}

\subsection{Earthworms, substrates, and treatments}

Non-clitellated earthworms of the species Eisenia fetida were obtained from a culture collection at the Estación Experimental del Zaidín (EEZ-CSIC), Granada, Spain. Vine shoots (organic carbon: $510 \mathrm{~g} \mathrm{~kg}^{-1}$, nitrogen: $13 \mathrm{~g} \mathrm{~kg}^{-1}$, moisture: $4 \%$ ), exhausted grape marc (organic carbon: $506 \mathrm{~g} \mathrm{~kg}^{-1}$, nitrogen: $17 \mathrm{~g} \mathrm{~kg}^{-1}$, moisture: $1 \%$ ), lees cake (organic carbon: $539 \mathrm{~g} \mathrm{~kg}^{-1}$, nitrogen: $30 \mathrm{~g} \mathrm{~kg}^{-1}$, moisture: $70 \%$ ), and vinasse sludge (organic carbon: $450 \mathrm{~g} \mathrm{~kg}^{-1}$, nitrogen: $75 \mathrm{~g} \mathrm{~kg}^{-1}$, moisture: $85 \%$ ) were collected from a vineyard, winery, and vinasse wastewater treatment plant (Tomelloso, Spain).

Three different organic substrates, each containing exhausted grape marc $(G)$, lees cake mixed with exhausted grape marc (LG) in a 2:1 ratio on a wet-weight basis and vinasse sludge mixed with vine shoots (SV) in a 2:1 ratio on a wet-weight basis, were prepared.

\subsection{Experimental layout}

For the pilot-scale experiment, three $1.5-\mathrm{m}^{2}$ vermicomposting beds with wooden frames were placed on a $5 \%$ slope and lined with a layer of plastic equipped with an outlet for leachate drainage underneath as reported previously [6]. The vermibeds were constructed in a $25-\mathrm{m}^{2}$ non-temperature-controlled greenhouse. Each vermibed was filled with a $15-\mathrm{cm}$ layer ( $20 \mathrm{~kg}$ dry weight) of one of the organic substrates described above. A belt of vermicomposted cattle manure, which was inoculated with $400 \mathrm{~g}$ of non-clitellated earthworms, was placed around this layer to provide an initial habitat for the earthworms and also to act as a source of microbial inoculum. During the 6-month vermicomposting period, no new substrate was added to the beds. The moisture content of the substrate in each bed was maintained at $70-80 \%$ by irrigation. Three $20 \times 20 \mathrm{~cm} 15-\mathrm{cm}$-deep samples were collected from each bed once a month. The number and weight of clitellated and non-clitellated earthworms were recorded, which were then transferred back to the beds. One sample per core $(15 \mathrm{~g})$ was stored in a plastic vial at $4{ }^{\circ} \mathrm{C}$ until enzyme activities were analyzed. At the end of the vermicomposting period, the earthworms were removed by hand, and the three vermicomposts were matured in piles for 2 months. Representative samples collected at initial time $(I)$ and after the vermicompost maturation (MV) were air-dried and then ground to determine changes in their chemical composition, organic matter fractions, and phytotoxicity. 
Chemico-structural properties of organic matter in the samples of mature vermicomposts were examined by using pyrolytic-gas chromatography (PY-GC) analysis. All values for chemical composition, organic matter fractions, enzyme activities, and phytotoxicity are expressed on sample dry mass basis.

\subsection{Chemical analysis, enzyme activities, and phytotoxicity analysis}

All analyses were performed in triplicate according to validated methods as briefly described below. The $\mathrm{pH}$ and electrical conductivity (EC) were measured with a glass electrode using a 1:10 sample/water (dw:v) ratio. Total organic carbon (TOC) and total nitrogen $(\mathrm{N})$ were determined with a LECO TruSpec CN analyzer (LECO Corporation, St. Joseph, USA). Water-soluble carbon (WSC) was extracted by mechanical shaking at $60^{\circ} \mathrm{C}$ for $1 \mathrm{~h}$ with distilled water (1:10 sample/water; $d w: v)$ and then determined with potassium dichromate and sulfuric acid at $160{ }^{\circ} \mathrm{C}$ for $30 \mathrm{~min}$. Subsequently, the amount of $\mathrm{Cr}^{+}$ produced by the reduction of $\mathrm{Cr}^{+}$was quantified spectrophotometrically at $590 \mathrm{~nm}$ [21]. Total extractable carbon (TEC) was extracted from $2 \mathrm{~g}$ of sample by mechanical shaking at $37^{\circ} \mathrm{C}$ for $2 \mathrm{~h}$ with $40 \mathrm{ml}$ of a solution consisting of $0.1 \mathrm{M} \mathrm{Na}_{2} \mathrm{P}_{4} \mathrm{O}_{7}$ and $0.1 \mathrm{M} \mathrm{NaOH}$. This extract was subsequently acidified to $\mathrm{pH} 1$ with $\mathrm{H}_{2} \mathrm{SO}_{4}$ and centrifuged at $3500 \mathrm{rpm}$ to precipitated the HA fraction. The HA solution was then obtained by dissolving the precipitate in $10 \mathrm{ml}$ of $0.5 \mathrm{M} \mathrm{NaOH}$. The $\mathrm{C}$ content in the WSC, TEC, and HA solutions was determined by dichromate oxidation followed by titration with ferrous ammonium sulfate. The humification ratio (HR) was calculated as HR\% $=100 \times \mathrm{TEC} / \mathrm{TOC}$ [22]. Total $\mathrm{P}$ was measured using the ammonium vanadomolybdate method. Total $\mathrm{K}$ and $\mathrm{Na}$ were measured by flame photometer and total $\mathrm{Ca}, \mathrm{Mg}, \mathrm{Fe}, \mathrm{Mn}, \mathrm{Cu}$, and $\mathrm{Zn}$ were determined by atomic absorption spectrometer after digestion of the samples with $\mathrm{HNO}_{3} / \mathrm{HClO}_{4}$ [23]. Hemicellulose, cellulose, and lignin were analyzed with the aid of the Ankom 200 Fiber Analyzer according to the Goering and van Soest method [24]. Total phenolic compound content was determined according to the method described by Khazaal et al. [25].

Dehydrogenase activity was determined by quantifying iodonitrotetrazolium formazan (INTF) produced after INT reduction from iodonitrotetrazolium formazan (INTF), according to the method published by Garcia et al. [26]. The p-nitrophenol (PNP) produced from 4-nitro-phenyl- $\beta$ D-glucanopyranoside (PNG) or 4-nitrophenyl phosphate (PNPP) were analyzed to determine $\beta$-glucosidase and acid phosphatase, respectively, as described by Nannipieri et al. [27]. Urease activity was determined by measuring $\mathrm{NH}_{4}{ }^{+}$ released from urea, using an ammonium selective electrode
(ORION Research Inc. Beverly, MA, USA), as described by Tabatabai [28].

Phytotoxicity was evaluated by using the germination index described by Zucconi et al. [29], which involves incubating cress seeds (Lepidium sativum) with 1:10 sample/ water (dw:v) extracts in darkness at $25^{\circ} \mathrm{C}$ for $24 \mathrm{~h}$. Distilled water was used as a control. Ten seeds were placed, in quintuplicate, in Petri dishes. The germination index (Gl) was calculated according to the formula $\mathrm{Gl}=(G / G o) \times(L / L o) \times 100$, where Go and Lo were, respectively, the percentage of germinated seeds and radicle growth of control.

\subsection{Chemico-structural properties of organic matter in mature vermicomposts: pyrolysis-gas chromatography (Py-GC) analysis}

Pyrolysis-gas chromatography was used to separate and quantify pyrolytic fragments from the rapid decomposition of organic matter under a controlled high temperature. A small quantity of each mature vermicompost placed in a microtube was analyzed with the aid of a CDS 190 Pyroprobe. The gas chromatograph spectrometer with a flame ionization detector (FID) and the analytical conditions used were previously described [19]. Pyrograms were interpreted by quantifying seven peaks corresponding to the major volatile pyrolytic fragments. Peak areas were normalized so that the area under each peak refers to the percentage of the total of the seven peaks selected (relative abundances).

\subsection{Statistical analysis}

Differences in the parameters determined over the time course of the study and between winery substrates in earthworm development and enzyme activity during vermicomposting and maturation were statistically tested using a oneway repeated measure analysis of variance (ANOVA) with mean separation based on Tukey's test. A paired-sample $t$ test was used to assess differences between the parameters measured in each initial winery substrate and mature vermicompost. Statistical analyses were conducted at confidence level $>95 \%(p<0.05)$ using SPSS 21 statistical software (IBM Corp., Armonk, NY, USA). In addition, the data set was subjected to principal component analysis (PCA) using the PC-Ord program in order to determine which parameters might be useful for characterizing the stabilized and mature vermicomposts as opposed to unprocessed wastes. 


\section{Results and discussion}

\subsection{Total biomass and number of earthworms during vermicomposting}

Although no earthworms were found in the different winery substrates $24 \mathrm{~h}$ after, the vermibeds were set up (zero time). Most of the inoculated earthworms migrated from the belts of cattle manure to the winery substrates after the first month of vermicomposting. In the exhausted grape marc $(G)$ substrate, earthworm biomass remained low throughout the vermicomposting period (Fig. 1a), with levels between 10 and $15 \mathrm{~g} \mathrm{~kg}^{-1}$ during the first 4 months. Similarly, earthworm number was low in that substrate, and most individuals lacked a developed clitellum (Fig. 1b). From the fourth month onward, earthworm biomass and the number declined significantly in $G$. In contrast to $G$, the mixture of lees cake with exhausted grape marc (LG) and that of vinasse sludge with vine shoots (SV) boosted earthworm biomass (Fig. 1a), reaching maximum biomass after 2 months $\left(51 \mathrm{~g} \mathrm{~kg}^{-1}\right.$ in LG and $68 \mathrm{~g} \mathrm{~kg}^{-1}$ in SV). Earthworm biomass then fell significantly in both substrates until the end of the vermicomposting period, and similar end values were observed $\left(12 \mathrm{~g} \mathrm{~kg}^{-1}\right.$ in LG and $15 \mathrm{~g} \mathrm{~kg}^{-1}$ in SV). Unlike the results for substrate $G$, the number of earthworms increased considerably in substrates $L G$ as well as in SV as a consequence of new earthworms hatched during the vermicomposting of those substrates. A $17 \%$ of the initially inoculated non-clitellated earthworms in LG reached the sexual maturity after 2 months, whereas a higher percentage of clitellated earthworms (53\%) was observed in SV after 3 months (Fig. 1b). However, from 4 months onward, all clitellated earthworms in those substrates lost their reproductive capacity, and only non-clitellated earthworms (juvenile and immature) were found at the end of the vermicomposting period. Clitellum loss and low earthworm weight imply that all fresh substrate LG and SV had been consumed and that additional substrate would be necessary in order to sustain earthworm growth and reproduction [30].

The results of this pilot study indicate that the exhausted grape marc assayed alone is an unsuitable earthworm food that produces a sub-optimal earthworm development. In LG and SV, the total earthworm biomass curves were similar to, or even higher than, those recorded in other vermicomposting processes with optimal
Fig. 1 Evolution of biomass (a) and total number of earthworms (b) during the vermicomposting period. $G$ exhausted grape marc, $L G$ lees cake mixed with exhausted grape marc, SV vinasse sludge mixed with vine shoots. Error bars represent the standard deviation. *A significant difference between substrates at a given time, ${ }^{¥} \mathrm{~A}$ significant difference between specific times for $G$ substrate, ${ }^{\&} A$ significant difference between specific times for LG substrate, ${ }^{\S} \mathrm{A}$ significant difference between specific times for SV substrate
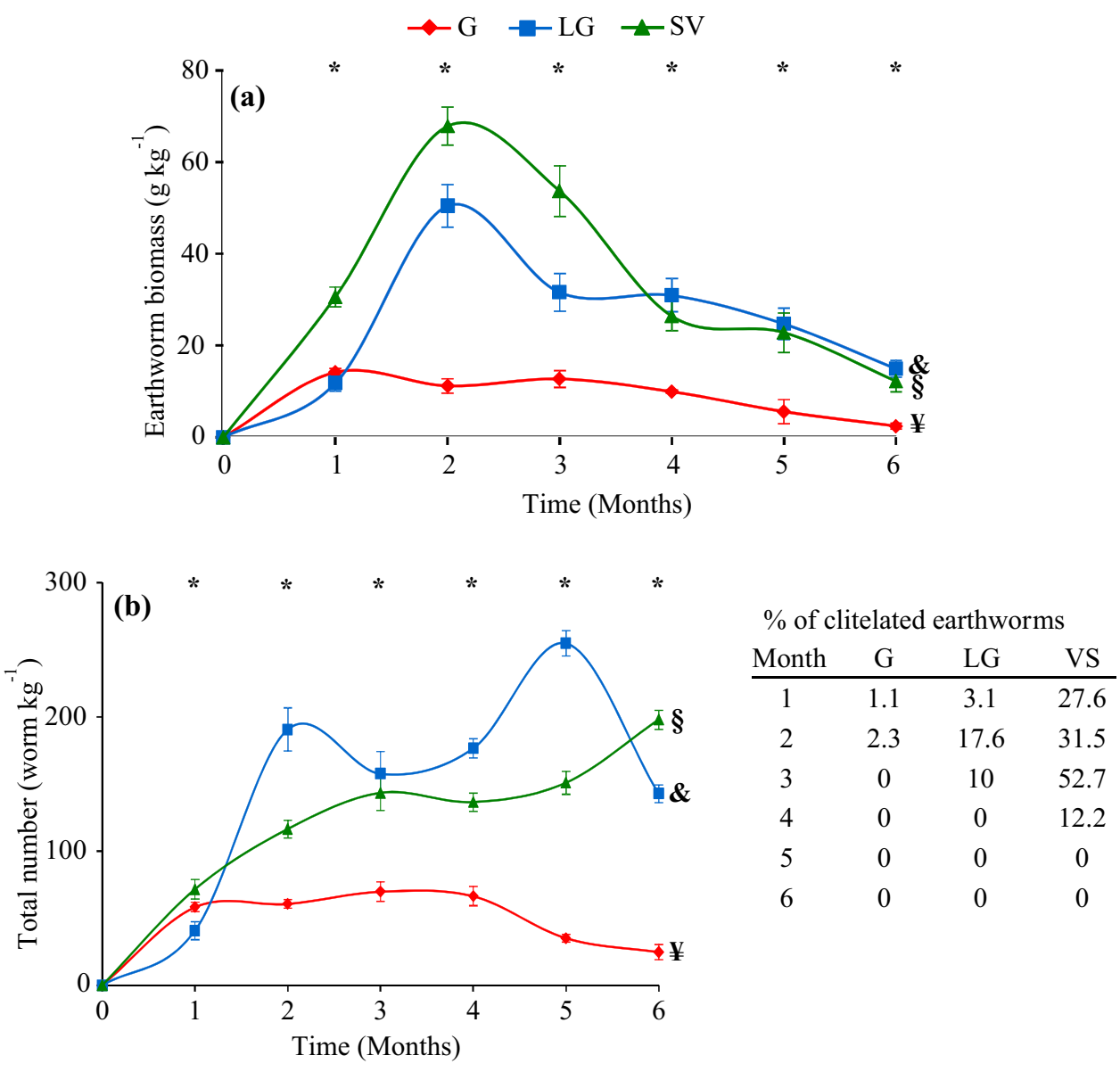
earthworm feeding material such as animal manure [31, 32]. Thus, both substrates could provide earthworms with sufficient quantities of easily metabolizable organic matter and nutrients to ensure their development and reproduction. In comparative terms, the vinasse sludge/vine shoot (SV) mixture was more effective earthworm feeding material than the lees/exhausted grape marc (LG) mixture, although both substrates would be a suitable growth media for E. fetida earthworms.

\subsection{Enzyme activity during vermicomposting and after maturation period}

Dehydrogenases (DHase) are intracellular enzymes involved in oxidative phosphorylation, which have been used to assess overall microbial activity in both continuous and non-continuous vermicomposting systems at a pilot scale $[13,16,33]$. In our study, DHase activity significantly rose, coinciding with the increase in total earthworm biomass, during the first 2 months of vermicomposting in the case of LG and SV (Fig. 2a). At the second month,
DHase activity was greater in SV $\left(111 \mu \mathrm{g}\right.$ INTF $\left.\mathrm{g}^{-1} \mathrm{~h}^{-1}\right)$ than in LG $\left(52 \mu \mathrm{g}\right.$ INTF $\left.\mathrm{g}^{-1} \mathrm{~h}^{-1}\right)$. This indicates that the digestive system of earthworms was able to break down the organic matter in both substrates, increasing the particle surface-to-volume ratio, and thereby the number and activity of microorganisms [5]. Moreover, as the fresh earthworm castings stimulate substrate microbial activity [34], the evolution of DHase activity was strongly related to the earthworm development during vermicomposting. This is corroborated by previous pilot-scale studies which reported increased DHase activity in response to an increase in total earthworm biomass and numbers during vermicomposting $[13,16,35]$. However, after 2 months, DHase activity significantly decreased until the end of the vermicomposting period, especially in SV. The observed decline indicates a reduction in microbial activity probably due to the mineralization of easily metabolizable organic materials in both substrates and to fewer fresh earthworm castings released in the final months of vermicomposting [35]. Consequently, no significant changes in DHase activity were recorded between the end of vermicomposting
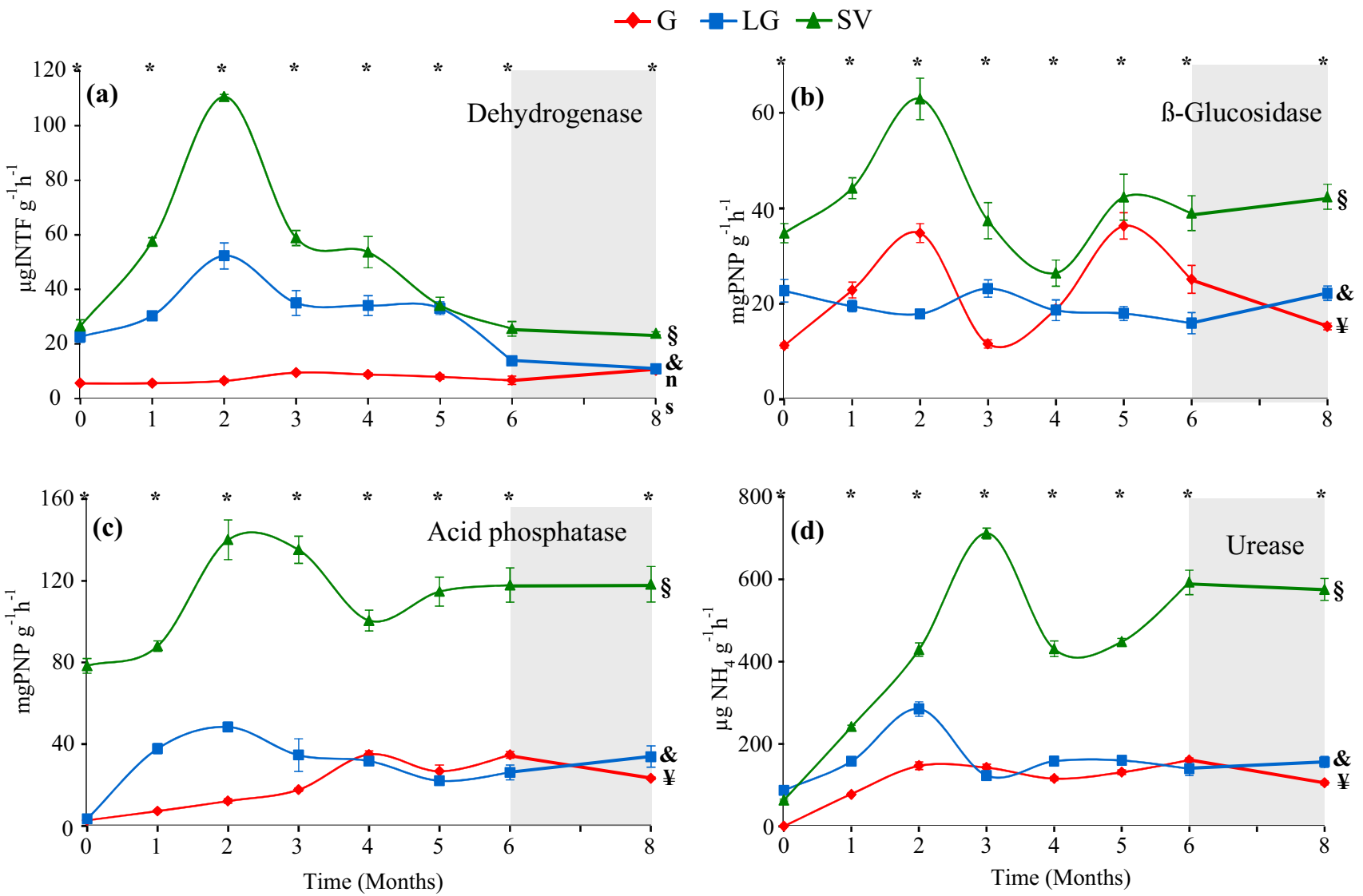

Fig. 2 Enzyme activities during the vermicomposting (square) and maturation (triangle) period. $G$ exhausted grape marc, $L G$ lees cake mixed with exhausted grape marc, $S V$ vinasse sludge mixed with vine shoots. Error bars represent the standard deviation. *A signifi-

cant difference between substrates at a given time, ${ }^{¥} \mathrm{~A}$ significant difference between specific times for $G$ substrate, ${ }^{\&} A$ significant difference between specific times for LG substrate, ${ }^{\S} \mathrm{A}$ significant difference between specific times for SV substrate 
and the subsequent maturation period. Unlike the results for LG and SV, in substrate $G$, DHase activity remained unvarying during vermicomposting and after maturation (Fig. 2a). The insignificant effect on microbial activity in that substrate would be related to the minor changes in earthworm biomass and numbers observed (Fig. 1a, b). Supporting this explanation, a close correlation between DHase activity and earthworm biomass was found in this study $(0.823, p<0.001)$. Therefore, DHase activity may be used as an acceptable biomarker for monitoring the time course of earthworm populations in the vermicomposting of winery wastes.

In the substrate SV, $\beta$-glucosidase activity was significantly higher than in the other winery substrates (Fig. 2b). This might be explained by the highest levels of watersoluble carbon in vinasse sludge (Table 1 ), the $C$ fraction which is easily available to $\beta$-glucosidases. In that substrate, $\beta$-glucosidase activity rose significantly during the first 2 months and fell between the second and fourth month. Finally, a less notable increase in $\beta$-glucosidase activity was observed at the fifth month, and then its value became stable until the end of the vermicomposting period. A similar overall pattern was observed for the substrate containing exhausted grape marc $(G)$, while the mixture of this winery waste with lees cake (LG) showed no significant change in $\beta$-glucosidase activity during the 6 months of vermicomposting and after the maturation period. $\beta$-glucosidases are key enzymes involved in cellobiose hydrolysis, providing energy to microorganisms in the form of $\beta$-glucose [36]. As previously reported by other authors $[5,6,17]$, during vermicomposting, increases in $\beta$-glucosidase activity were related to boosted microbial metabolic activity due to the release of cellobiose by hydrolysis of cellulose and hemicellulose. Consequently, the highest $\beta$-glucosidase activity observed during the vermicomposting of SV may also be related to the largest initial contents of cellulose and hemicellulose in that substrate (Table 1). On the other hand, $\beta$-glucosidase activity might be repressed by the lignin content in $G$ and LG, which were higher than in SV (Table 1). A large proportion of lignin might reduce $\beta$-glucosidase activity in those substrates as a consequence of repressive phenomena caused by interactions with lignin structures or lignin-carbohydrate complexes [37]. During the maturation period, $\beta$-glucosidase activity increased significantly in LG and SV, while a significant decline was observed in $G$. This was probably due to improved earthworm growth in SV and LG which boosts the proliferation of cellulolitic microorganisms in the vermicomposts and releases cellobiose during the maturation period. The decline in $\beta$-glucosidase activity might be associated with lower cellobiose content in the substrate and/or glucose accumulation through back inhibition of $\beta$-glucosidase synthesis [38].

As reported for other kinds of sludge [35], the acid phosphatase activity recorded higher levels during the vermicomposting of SV as compared to the other substrates assayed (Fig. 2C). This is indicative of higher abundance of organic phosphate compounds in vinasse sludge, which may induce enzyme synthesis. In the vermicomposting of SV, the acid phosphatase activity significantly rose during the first 2 months, continuing with a fall until the fourth month. Finally, that enzyme activity slightly increased, remaining stable during the vermicomposting and maturation period. In $G$ and LG, acid phosphatase activity recorded lower values, which increased after two (in LG) and 4 months (in $G$ ) of vermicomposting. From the second to the fourth month, the acid phosphatase activity lightly decreased in the case of LG. In both substrates the acid phosphatase activity remained steady until the end of the vermicomposting and maturation period. Acid
Table 1 Organic matter fractions and germination index of initial substrates (l) and mature vermicomposts (MV) of exhausted grape $\operatorname{marc}(G)$, lees cake mixed with exhausted grape marc mixed with (LG) and vinasse sludge mixed with vine shoots (VS)

\begin{tabular}{|c|c|c|c|c|c|c|}
\hline & \multicolumn{2}{|l|}{$G$} & \multicolumn{2}{|l|}{ LG } & \multicolumn{2}{|l|}{ VS } \\
\hline & I & VM & I & VM & I & MV \\
\hline $\mathrm{TOC} \mathrm{g} \mathrm{kg}^{-1}$ & $502 \pm 7^{*}$ & $344 \pm 13$ & $475 \pm 10^{*}$ & $280 \pm 17$ & $482 \pm 10^{*}$ & $295 \pm 13$ \\
\hline WSC $\mathrm{g} \mathrm{kg}^{-1}$ & $5.8 \pm 0.5^{*}$ & $1.2 \pm 0.2$ & $6.6 \pm 0.4^{*}$ & $1.3 \pm 0.1$ & $17.4 \pm 1.5^{*}$ & $1.5 \pm 0.2$ \\
\hline Hemicellulose $\mathrm{g} \mathrm{kg}^{-1}$ & $90 \pm 1^{*}$ & $68 \pm 7$ & $77 \pm 5$ & $70 \pm 5$ & $210 \pm 1^{*}$ & $108 \pm 4$ \\
\hline Cellulose $\mathrm{g} \mathrm{kg}^{-1}$ & $91 \pm 1$ & $103 \pm 1^{*}$ & $103 \pm 2$ & $101 \pm 5$ & $197 \pm 10^{*}$ & $69 \pm 2$ \\
\hline Lignin $\mathrm{g} \mathrm{kg}^{-1}$ & $502 \pm 4^{*}$ & $434 \pm 7$ & $447 \pm 12$ & $372 \pm 8^{*}$ & $168 \pm 4$ & $255 \pm 7^{*}$ \\
\hline TEC $\mathrm{g} \mathrm{kg}^{-1}$ & $33 \pm 4$ & $62 \pm 8^{*}$ & $61 \pm 6$ & $96 \pm 7^{*}$ & $68 \pm 6$ & $247 \pm 13^{*}$ \\
\hline $\mathrm{HA} \mathrm{g} \mathrm{kg}{ }^{-1}$ & $4.7 \pm 1$ & $33 \pm 2^{*}$ & $22 \pm 2$ & $62 \pm 6^{*}$ & $38 \pm 3$ & $142 \pm 11^{*}$ \\
\hline$C / N$ & $29 \pm 1$ & $22 \pm 2$ & $25 \pm 2^{*}$ & $14 \pm 1$ & $17 \pm 1^{*}$ & $11 \pm 1$ \\
\hline HR\% & $6.5 \pm 0.8$ & $18 \pm 2^{*}$ & $13 \pm 1$ & $34 \pm 2^{*}$ & $14 \pm 2$ & $84 \pm 8^{*}$ \\
\hline Polyphenols $\mathrm{g} \mathrm{kg}^{-1}$ & $2.9 \pm 0.2^{*}$ & $1 \pm 0.0$ & $6.6 \pm 0.9^{*}$ & $1.2 \pm 0.1$ & $17.8 \pm 0.2^{*}$ & $1.2 \pm 0.2$ \\
\hline Gl\% & 0 & $103 \pm 5^{*}$ & $24 \pm 5$ & $93 \pm 3^{*}$ & 0 & $90 \pm 4$ \\
\hline
\end{tabular}

Values (dry mass) are mean $\pm \mathrm{SD}(n=3)$. For each treatment, the asterisk $\left.{ }^{*}\right)$ denotes significant differences ( $p<0.05$, paired-sample $t$ test) between initial substrate and mature vermicompost 
phosphatases, which catalyze the hydrolysis of organic phosphomonoesters to inorganic phosphates for plant uptake [39], are agriculturally valuable enzymes. Increases in acid phosphatase activity were due to the presence of organic phosphate compounds in the different winery substrates assayed or to the release of P-esters, which trigger the synthesis of acid phosphatases by microorganisms and earthworms [40]. In addition, lower phosphatase activity during vermicomposting may be caused by changes in humic-matrix-enzyme interactions. The formation of humic-enzyme complexes could also make enzymes less active and less accessible to organic-P substrates [41]. Finally, acid phosphatase stability at the end of maturation period means that the winery substrates assayed still contained sufficient available organic $P$ as well as that those enzymes have a degree of activity in the humus matrix [42].

Urease activity, which is involved in the final stages of organic N compound degradation [3], increased significantly during the first 2 months in all substrates assayed, reaching in the third month of vermicomposting of SV, the highest peak of urease activity $\left(711 \mathrm{\mu g} \mathrm{NH}_{4} \mathrm{~g}^{-1} \mathrm{~h}^{-1}\right)$. Increased urea activity during the initial stages of vermicomposting in these substrates was due to a partial degradation in easily metabolizable organic $\mathrm{N}$ compounds such as proteins and polypeptides, which might be more abundant in SV, as indicated by its initial value of organic $\mathrm{N}$ (Table 2). The sharp decline in urease activity recorded in SV (from the 3rd to 4th month) and LG (from the 2nd to $3 \mathrm{rd}$ ) was caused by reduced urea availability in these substrates and/or by the inhibition of urease activity by the accumulation of $\mathrm{NH}_{4}{ }^{+}$, an inhibitor of urease biosynthesis [43]. The release of $\mathrm{NH}_{4}^{+}$could be the result of the high mineralization of proteins from winery. Lastly, urease activity rose significantly in the case of SV. This rise was due to the disappearance of ammonia from these substrates or to urease resynthesis, which usually occurs when the activity of this enzyme falls to minimum levels [30]. Urease activity remained stable during maturation of all the vermicomposts. As with acid phosphatase, the stability of urease activity during maturation means that most of these extracellular enzymes bind to humic matter in the substrates [42].

\subsection{Chemical changes caused by vermicomposting and maturation}

Vermicomposting and subsequent maturation were effective in raising the acidic $\mathrm{pH}$ of winery waste substrates, which reached neutral values in the matured vermicomposts (Table 2). This rise could be explained by the disappearance of organic acids and/or by protein mineralization in these substrates, which could generate ammonium [44]. Electrical conductivity was significantly lower in mature vermicomposts than in the initial substrates, which might be due to the loss of soluble salts caused by leaching and/ or microbial immobilization and/or to insoluble salt formation in the organic substrates during vermicomposting and maturation [5].

Nitrogen declined significantly in all substrates, except for the mixture of lees cake and exhausted grape marc (LG) (Table 2). $\mathrm{N}$ fell in mature vermicompost might be explained because part of its initial content was incorporated into the earthworm's body protein, which was lost when the earthworms were removed after the vermicomposting period. In addition, some $\mathrm{N}$ may have been lost through ammonia volatilization from ammonium accumulated in the substrates due to the $\mathrm{pH}$ increase (Table 2).
Table 2 Chemical properties of initial substrates $(I)$ and mature vermicomposts (MV) of exhausted grape marc $(G)$, lees cake mixed with exhausted grape marc mixed (LG) and vinasse sludge mixed with vine shoots (VS)

\begin{tabular}{|c|c|c|c|c|c|c|}
\hline & \multicolumn{2}{|l|}{$G$} & \multicolumn{2}{|l|}{ LG } & \multicolumn{2}{|l|}{ VS } \\
\hline & 1 & $\mathrm{MV}$ & 1 & $\mathrm{MV}$ & 1 & $\mathrm{MV}$ \\
\hline $\mathrm{pH}$ & $6.4 \pm 0.1$ & $6.9 \pm 0.1^{*}$ & $6.3 \pm 0.1$ & $7.3 \pm 0.1^{*}$ & $6.3 \pm 0.2$ & $7.3 \pm 0.1^{*}$ \\
\hline 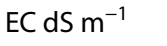 & $1.5 \pm 0.1^{*}$ & $0.8 \pm 0.1$ & $5.3 \pm 0.1^{*}$ & $1.6 \pm 0.1$ & $6.7 \pm 0.1^{*}$ & $1.3 \pm 0.1$ \\
\hline $\mathrm{Ng} \mathrm{kg}^{-1}$ & $17 \pm 0.2^{*}$ & $16 \pm 0.6$ & $19.3 \pm 0.9$ & $19.8 \pm 0.5$ & $28.8 \pm 0.5^{*}$ & $26 \pm 0.3$ \\
\hline $\mathrm{Pg} \mathrm{kg}^{-1}$ & $2.0 \pm 0.1$ & $2.5 \pm 0.2^{*}$ & $1.7 \pm 0.2$ & $3.3 \pm 0.2^{*}$ & $3.1 \pm 0.2$ & $5.3 \pm 0.4^{*}$ \\
\hline $\mathrm{Kg} \mathrm{kg}^{1}$ & $3.7 \pm 0.1^{*}$ & $2.9 \pm 0.2$ & $7.4 \pm 0.2^{*}$ & $4.6 \pm 0.2$ & $8.8 \pm 0.2^{*}$ & $5.8 \pm 0.3$ \\
\hline Ca g kg ${ }^{-1}$ & $13.7 \pm 0.3$ & $25.6 \pm 0.6^{*}$ & $20.6 \pm 1$ & $32.0 \pm 1,2^{*}$ & $7.6 \pm 0.1$ & $34.4 \pm 3^{*}$ \\
\hline $\mathrm{Mg} \mathrm{g} \mathrm{kg}^{-1}$ & $1.1 \pm 0.1$ & $4.6 \pm 0.4^{*}$ & $1.3 \pm 0.1$ & $4.8 \pm 0.5^{*}$ & $1.7 \pm 0.3$ & $8.7 \pm 0.4^{*}$ \\
\hline $\mathrm{Na} \mathrm{mg} \mathrm{kg}^{-1}$ & $183 \pm 11^{*}$ & $86 \pm 5$ & $152 \pm 2^{*}$ & $79 \pm 2$ & $2960 \pm 106^{*}$ & $1437 \pm 104$ \\
\hline Fe $\mathrm{mg} \mathrm{kg}^{-1}$ & $613 \pm 20$ & $1732 \pm 98^{*}$ & $803 \pm 14$ & $2629 \pm 84^{*}$ & $2256 \pm 16$ & $4715 \pm 77^{*}$ \\
\hline $\mathrm{Mn} \mathrm{mg} \mathrm{kg}^{-1}$ & $9 \pm 2$ & $54 \pm 2^{*}$ & $10 \pm 1$ & $65 \pm 2^{*}$ & $46 \pm 2$ & $214 \pm 10^{*}$ \\
\hline Cu mg kg ${ }^{1}$ & $15 \pm 1$ & $28 \pm 2^{*}$ & $20 \pm 1$ & $42 \pm 2^{*}$ & $205 \pm 8$ & $254 \pm 6$ \\
\hline $\mathrm{Zn} \mathrm{mg} \mathrm{kg}^{1}$ & $6 \pm 1$ & $151 \pm 6^{*}$ & $6 \pm 1$ & $131 \pm 2^{*}$ & $82 \pm 3$ & $311 \pm 7^{*}$ \\
\hline
\end{tabular}

Values (dry mass) are mean \pm SD $(n=3)$. The asterisk $\left(^{*}\right)$ denotes significant differences $(p<0.05$, pairedsample $t$ test) in each parameter between the initial substrate and mature vermicompost 
Furthermore, earthworm activity facilitated the process oxidation of ammonia into nitrates, which might partly drained out by water excess in the vermibeds [45]. A recent study published by Huang et al. [46] pointed out that the numbers and community richness of ammonia-oxidizing bacteria and archaea in a mixture of fruit and vegetable wastes increased by vermicomposting using $E$. fetida.

On the other hand, total concentrations of $\mathrm{P}, \mathrm{Ca}, \mathrm{Mg}$, $\mathrm{Fe}, \mathrm{Mn}, \mathrm{Cu}, \mathrm{Zn}$, and $\mathrm{Ni}$ increased significantly in all substrates after vermicomposting and maturation (Table 2 ). This effect may mainly be attributed to the earthworms reduced waste mass by enhancing organic matter mineralization, as indicated by significant strong reductions in TOC content in mature vermicomposts (Table 1). A similar rise in total nutrient levels has been observed in other types of vermicomposts produced from different organic substrates such as greenhouse vegetable waste, manure, or kitchen wastes $[17,46,47]$.

By contrast, total potassium and sodium concentrations were significantly lower in the mature vermicomposts than in the initial winery substrates (Table 2), which might be due to the leaching of these elements via water drainage. A similar decline in total $\mathrm{K}$ and other soluble cations has been reported in final-stage of vermicomposting of sugarcane wastes mixed with cow dung [49], although some increases in this element have also been reported in the case of other vermicomposts produced from different wastes mixtures such as a composed of rice straw and kitchen waste [48]. Regarding heavy metals content in the produced vermicomposts, although the concentration of $\mathrm{Cu}$ and $\mathrm{Zn}$ increased after vermicomposting and maturation, the levels of these metals meet European Union Eco-label requirements for organic production, permitting the mature vermicomposts to be used as organic amendments in agriculture [50]. In addition, the concentrations of $\mathrm{Cd}, \mathrm{Co}, \mathrm{Ni}$, and $\mathrm{Cr}$ were found to be below detection limits (under $0.02 \mathrm{mg} \mathrm{kg}^{-1}$ ) in both the initial substrates and mature vermicomposts, which could be due to their low content levels in winery wastes.

\subsection{Changes in organic matter fractions and germination index caused by vermicomposting and maturation}

As observed in other non-continuous vermicomposting processes of similar mixtures of winery wastes, which were conducted by using a lower density of earthworms [51], total organic carbon (TOC) content significantly diminished in the three different winery substrates after vermicomposting and maturation period (Table 1). In comparison with that study previously published [51], a greater reduction in TOC was attained in the case of the exhausted grape marc assayed alone. On the other hand, strong reductions in water-soluble carbon (WSC) (SV $91 \%>$ LG $80 \%>$ G 79\%), which is an easily metabolizable organic matter fraction [29], exceeded the falls in TOC (LG $41 \%>$ SV $39 \%>$ G 31\%). Although some organic fractions in the substrates were converted into earthworm biomass, most of the reductions in TOC and WSC during vermicomposting may be attributed to microorganism activity and gut enzymes in the intestines of earthworms as well as to heterotrophic microorganisms present in the organic substrates, which mineralize and transform carbon compounds into simpler forms and then into $\mathrm{CO}_{2}$ [3]. This may be deduced from greater TOC reductions observed in LG and SV, substrates which also recorded higher DHase activity during the vermicomposting process as compared to the substrate $G$ (Fig. 2a). In addition, the organic component lignin, which is well known as more recalcitrant than hemicellulose and cellulose to degradation by earthworms and microorganisms, was more abundant in $G\left(502 \mathrm{~g} \mathrm{~kg}^{-1}\right.$; Table 1) than in the other winery substrates.

Lignin and hemicellulose content in $G$ significantly decreased after vermicomposting and maturation, whereas cellulose content increased (Table 1). In the case of $L G$, although lignin content also decreased significantly after vermicomposting and maturation, no statistical differences in cellulose and hemicellulose content were observed. This could be related to the slight changes in $\beta$-glucosidase activity recorded during the vermicomposting stage of that substrate (Fig. 2b). In contrast to $G$ and LG, lignin content in SV significantly increased after vermicomposting and maturation, whereas stronger reductions in hemicellulose and cellulose content were observed. This divergence may be due to higher initial content of hemicellulose and cellulose in SV in comparison to $G$ and LG. Those polysaccharides could be decomposed by the joint action of earthworms and microorganisms during vermicomposting, and by the microorganisms involved in maturation. This deduction is supported by $\beta$-glucosidase activity pattern, which increased when earthworm population reached the highest value, and also after the maturation step in SV (Fig. 2b). This is in agreement with previous reports, which stated that microorganisms in vermicomposting processes are the main responsible for the final decomposition of cellulose, a food source for earthworms, whose cellulolytic activity plays a key role in their digestive system [52]. In addition, microflora inhabitant of the earthworm guts and the stimulation of microorganisms in organic substrates by earthworm activities might increase lignolytic degradation during vermicomposting. This may explain the reductions in lignin fraction observed in $G$ and LG. Conversely, increased relative lignin content in mature vermicomposts has been previously reported after vermicomposting of tomato-plant debris mixed with papermill sludge as a consequence of waste mass reduction and 
accumulation of recalcitrant lignin fraction, which is more resistant to be digested by earthworms and microorganisms in comparison with hemicellulose or cellulose [18]. According to these authors, lignin concentration in lignocellulosic wastes might also increase by poly-condensation and neosynthesis phenomena, which take place during the final stages of vermicomposting and maturation.

As mentioned above, a substantial portion of original organic matter was mineralized to carbon dioxide during vermicomposting and maturation process, with the residual portion being transformed into stabilized, refractory organic matter which chemically resembles native-soil humic substances. This finding is clearly relevant to our study, as total extractable carbon (TEC), a measurement of total carbon content in humic substances, and levels of humic acid (HA), the principal component of humic substances, were significantly higher in the mature vermicomposts than in the initial winery substrates (Table 1). TEC rose approximately twofold in $G$ and $L G$ and roughly fourfold in SV after vermicomposting and maturation, while $H A$ in $G$, LG, and especially in SV increased by $47 \%$, $36 \%$, and $74 \%$, respectively. Consequently, the humification ratio (HR) increased significantly after the vermicomposting and maturation. Similar humic transformations have been previously found after analogous vermicomposting processes of the same winery wastes, although a larger amount of substrate was biotransformed in smaller vermibeds $\left(1 \mathrm{~m}^{2}\right)$ in that previous study [51]. In addition to the increases in $\mathrm{HR}$, lower $\mathrm{C} / \mathrm{N}$ ratio in the mature vermicomposts, as compared with those recorded in the initial substrates, are indicative of a high degree of stability and a prolonged synthesis of organic components resistant to microbial degradation [53]. In comparative terms, this humification effect was more marked in SV and, to a lesser extent, in LG, respectively, recording $84 \%$ and $34 \%$ of organic matter content in mature vermicomposts that can be regarded as humified. The higher rates of humification recorded in the mature vermicomposts from SV and $L G$ agree with the higher levels of mineralization (i.e., TOC reduction) recorded in those substrates, while these organic matter processes were much less pronounced in $G$.

All the winery wastes assayed recorded a low germination index $(\mathrm{Gl})$, which approached zero in the initial substrates $G$ and SV (Table 1). Different factors, such as low molecular weight fatty acids, phenolic compounds, ammonium nitrogen, aliphatic and aromatic amines, heavy metals or high electrical conductivity, can intensify phytotoxicity in organic amendments [23]. The different winery waste substrates assayed contained moderate amounts of polyphenol compounds (Table 1) and salt measured as electrical conductivity (Table 2), with larger amounts detected in SV. The reduction in polyphenolic compounds and salinity caused by vermicomposting and maturation
(Tables 1 and 2) led to an increase of over $90 \%$ in Gl values in all substrates, which can therefore be regarded as non-phytotoxic mature vermicomposts with organic matter suitable for agricultural practices [29]. The GI values observed in this pilot-scale study were higher than those reported by a previous laboratory study of feasibility of vermicomposting for the same winery waste substrates [3]. This may be explained because a greater reduction in the final amounts of polyphenol compounds was accomplished by this pilot-scale study.

\subsection{Chemico-structural properties of organic matter in mature vermicomposts}

Table 3 shows the relative abundance of the main pyrolytic fragments observed in the three mature vermicomposts differed in terms of relative abundance. Overall, acetonitrile (E1) and phenol (Y) were the least abundant fragments in the three mature vermicomposts, while benzene (B) and acetic acid (K) were the most abundant. In comparative terms, the mature vermicompost from SV contained larger amounts of toluene (E3) and acetonitrile (E1) and smaller amounts of acetic acid (K) and benzene (B) than the mature vermicomposts from $G$ or LG. Differences between the latter two mature vermicomposts were less apparent, although the vermicompost from LG contained a larger proportion of benzene (B) than the vermicompost from $G$.

Table 3 Relative abundances (\%) of main pyrolytic peaks for acetonitrile $(E 1)$, phenol $(Y)$, acetic acid $(K)$, benzene $(B)$, pyrrole $(O)$, furfural $(\mathrm{N})$ and toluene (E3), sums of aliphatic (AL) and aromatic (AR) compounds and pyrolytic indices of mineralization (N/O) and $\%$ humification $(B+E 3)$ rates in the mature vermicomposts from $G$, LG and VS

G LG VS

\begin{tabular}{lrrr}
\hline Pyrolytic fragments & & & \\
E1\% & $3.2 \pm 0.2 \mathrm{~b}$ & $1.3 \pm 0.1 \mathrm{c}$ & $5.6 \pm 0.2 \mathrm{a}$ \\
Y\% & $3.6 \pm 0.3 \mathrm{~b}$ & $4.7 \pm 0.2 \mathrm{a}$ & $4.5 \pm 0.4 \mathrm{a}$ \\
K\% & $28.3 \pm 0.5 \mathrm{~b}$ & $30.4 \pm 0.7 \mathrm{a}$ & $17.8 \pm 0.3 \mathrm{c}$ \\
B\% & $22.8 \pm 0.5 \mathrm{~b}$ & $32.8 \pm 0.3 \mathrm{a}$ & $14.7 \pm 0.2 \mathrm{c}$ \\
O\% & $11.4 \pm 0.3 \mathrm{~b}$ & $7.5 \pm 0.5 \mathrm{c}$ & $12 \pm 0.8 \mathrm{a}$ \\
N\% & $14.3 \pm 0.7 \mathrm{a}$ & $11.2 \pm 0.4 \mathrm{~b}$ & $11.2 \pm 0.6 \mathrm{~b}$ \\
E3\% & $16.4 \pm 0.6 \mathrm{~b}$ & $12.0 \pm 0.4 \mathrm{c}$ & $34.2 \pm 0.7 \mathrm{a}$ \\
AL (K+N+E1)\% & $45.8 \pm 0.3 \mathrm{a}$ & $42.9 \pm 1 \mathrm{~b}$ & $34.6 \pm 0.9 \mathrm{c}$ \\
AR (B+E3+Y)\% & $54.2 \pm 0.5 \mathrm{c}$ & $57.0 \pm 0.7 \mathrm{~b}$ & $65.4 \pm 0.5 \mathrm{a}$ \\
Pyrolytic indices & & & \\
N/O & $1.26 \pm 0.09 \mathrm{a}$ & $1.49 \pm 0.05 \mathrm{a}$ & $0.93 \pm 0.11 \mathrm{~b}$ \\
B + E3\% & $39.3 \pm 0.1 \mathrm{c}$ & $44.8 \pm 0.4 \mathrm{~b}$ & $48.9 \pm 0.9 \mathrm{a}$ \\
\hline
\end{tabular}

Values (dry mass) are mean $\pm \mathrm{SD}(n=3)$. Means in the same row with different letters differ significantly $p<0.05$ 
Acetonitrile (E1) is associated with amino acids and proteins decomposition by a diverse range of microbiological processes during vermicomposting and maturation. Acetic acid $(\mathrm{K})$ is preferentially derived from the pyrolysis of lipids, fats, waxes, cellulose, and carbohydrates. High acetic acid levels indicate strong organic matter resistance to biodegradation [54]. Benzene (B) and toluene (E3) are basically derived from condensed aromatic structures of stable (humified) organic matter, while pyrrole $(0)$ is originated from condensed aromatic structures and nitrogenated compounds such as nucleic acids and proteins. These molecules are resistant to biodegradation and constitute energy reserves, whose prevalence indicates the absence of labile organic matter [54], which was degraded mainly during vermicomposting. Furfural $(\mathrm{N})$ and phenol $(\mathrm{Y})$ are derived from carbohydrates, lignin, and condensed lignocellulosic structures.

A general analysis of the results indicates that the vermicomposts produced from LG and SV recorded more similar percentages of these pyrolytic fragments than the vermicompost from $G$ in spite of the vermicompost from LG was produced by using a substrate mixture which contained a third of $G$. These results suggest that decomposition and humification process during vermicomposting are more influenced by the earthworm development and microbial activity than by the differences in carbohydrates (hemicellulose and cellulose) and lignin content in the initial wastes.

With regard to the percentages of mineralizable aliphatic (AL) and benzene-derived aromatic (AR) fractions (Table 3), which are considered to be two prime organic matter components in soils and organic amendments [55], the fraction of aromatic (AR) compounds was larger than the fraction of aliphatic $(A L)$ compounds in the three vermicomposts. The vermicompost from SV recorded the highest AR enrichment and the lowest level of AL. Moreover, the differences in the vermicomposts were more clearly reflected in the pyrolytic indices of organic matter mineralization and humification (Table 3). The mineralization index (N/O) expresses the ratio of furfural to pyrrole [19] and is considered to be an index of humus stability, which is lower for more stabilized humus since pyrrole $(\mathrm{O})$ is chemically and microbiologically more stable than furfural (N) [56]. Thus, the vermicompost from SV had a more mineralized and stable organic matter than the vermicomposts from $G$ or LG. The B/E3 ratio, reported as a valid index for determining degree of humification in soil organic matter [20], is based on the principle of benzene (B) is derived primarily from the pyrolytic degradation of condensed aromatic structures and toluene (E3) from aromatic uncondensed rings with aliphatic chains. In organic materials such as sludge, the sum of benzene and toluene $(B+E 3)$ is considered to be a more accurate index of humification [57] than the $\mathrm{B} / \mathrm{E} 3$ ratio, which is used for soils. The $B+E 3$ humification index was higher in the vermicompost from SV, which means that the condensation, aromaticity, and stability of its organic matter were higher as compared to the organic matter in the other vermicomposts. Therefore, the vermicompost from SV contained the most evolved organic matter as indicated by the highest humification index (suggesting high transformation of simple organic matter into humic substances) in addition to the lowest mineralization index (indicative of highly stable organic matter). As compared with a previous study, which described the vermicomposting of anaerobic and aerobic municipal sewage sludge [58], the vermicompost from SV recorded higher $\mathrm{B}+\mathrm{E} 3$ humification index and lower mineralization index (N/O) than the values of those indices observed in the most stable and humified vermicompost from sludge (produced from $50 \%$ aerobic and $50 \%$ anaerobic sludge).

\subsection{Principal component analysis}

Enzyme activities data, total organic carbon, water-soluble carbon, humic acids, and germination index recorded in the three initial winery waste substrates and the corresponding mature vermicomposts were used to perform principal component analysis (PCA) (Fig. 3). As the first and second principal components (PC 1 and PC 2) accounted for $88.4 \%$ of the variance, PCA can be regarded as suitable to compare initial substrates and mature vermicomposts according to the parameters listed above, which define the degree of stability and maturity of organic amendments. Sample distribution in the plane defined by PC1 shows a gap of the initial substrates and mature vermicomposts depending on the type of winery waste substrate assayed $(G, L G$, and SV). This suggests that the biochemical characteristics and degree of stability and maturity of the vermicomposts are mainly determined by the nature of the initial winery substrates. On the other hand, the plane defined by PC2 clearly shows a gap between the initial substrates, which had lower degrees of stability and maturity, and the final vermicomposts which were stable and mature. This gap separation is mainly based on TOC that recorded higher values in the initial substrates than in the mature vermicomposts, as indicated by the arrow facing toward the initial substrates, as well as on $\mathrm{Gl}$, which arrow points toward the mature vermicomposts, as indicative of higher values of germination indices. PCA shows that the pilot-scale vermicomposting and maturation processes biotransformed the initial winery waste substrates into final products with a higher degree of stability and maturity. This is especially evidenced by the vermicompost from SV, which showed the widest difference separation from its parent substrate along the PC2 plane. In addition, 


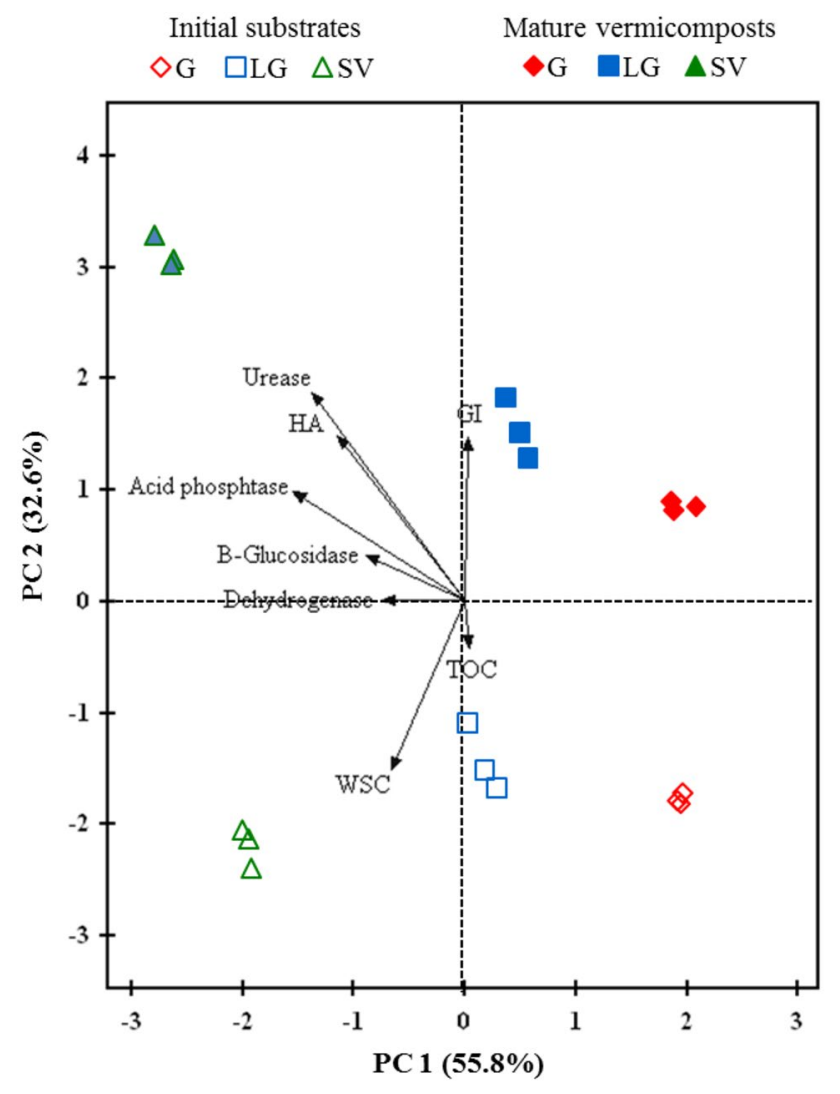

Fig. 3 Principal component analysis (PCA) of germination index (GI), total organic carbon (TOC), water-soluble carbon (WSC), humic acid (HA), as well as dehydrogenase, $\beta$-glucosidase, acid phosphatase and urease activity in initial substrates and mature vermicomposts

along PC1 plane, the vermicompost from SV can be differentiated from the other vermicomposts on the basis of its higher urease, acid phosphatase and $\beta$-glucosidase activity, as well as its humic acid content.

\section{Conclusions}

The present study demonstrates at pilot scale that the mixtures between different winery wastes such as those of recalcitrant lignocellulosic nature (exhausted grape marc or vine shoots), with those that have high $\mathrm{N}$ contents (lees cake or vinasse sludge), allows their recycling through vermitechnology. This environmentally friendly technology can be used to obtain mature organic winery wastes amendments, which are rich in $\mathrm{N}$ and other plant nutrients, humic content, and microbial enzyme activity as well as low electrical conductivity, phytotoxicity and $C / N$ ratios. Particularly, the mixture of vine shoot and biosolid vinasse was the most suitable substrate for vermitechnology at large scale, according to the earthworm development and enzyme activity patterns. Furthermore, the mature vermicompost from the mixture of vinasse sludge and vine shoot contained the most evolved organic matter as indicated by its indices of higher humification and lower mineralization as compared with the other mature vermicomposts. Nevertheless, all the vermicomposts produced from the different mixture of winery wastes can be considered as value-added stabilized and mature organic materials, which could therefore be used as alternative organic amendments in conventional and organic farming, as well as for sustainable soil protection, with the aim of raising stable organic matter content in soil. This is of particular interest in the Mediterranean basin and in arid and semiarid regions, whose widespread viticulture activity combined with vermitechnological recycling of winery wastes should reduce expenditures devoted to traditional manure and synthetic fertilizers.

Acknowledgements This study was co-funded by the Junta de Andalucía (Project AGR-138) and the European FEDER program. The authors wish to thank Celia Cifuentes for her technical assistance and Michael O'Shea for proofreading the manuscript.

\section{Compliance with ethical standards}

Conflict of interest On behalf of all authors, the corresponding author states that there is no conflict of interest.

\section{References}

1. EC-Eurostat (2017) https://ec.europa.eu/agriculture/wine/stati stics_en.OpenDocument. Accessed 10 July 2019

2. Devesa-Rey R, Vecino X, Varela-Alende JL, Barral MT, Moldes $A B$, Cruz JM (2011) Valorization of winery waste vs. the costs of not recycling. Waste Manag 31:2327-2335. https://doi. org/10.1016/j.wasman.2011.06.001

3. Nogales R, Cifuentes C, Benitez E (2005) Vermicomposting of winery wastes: a laboratory study. J Environ Sci Heal B 40:659673. https://doi.org/10.1081/PFC-200061595

4. Ioannou LA, Li Puma G, Fatta-Kassinos D (2015) Treatment of winery wastewater by physicochemical, biological and advanced processes: a review. J Hazard Mater 286:343-368. https://doi.org/10.1016/j.jhazmat.2014.12.043

5. Nogales R, Romero E, Fernández-Gómez MJ (2014) Vermicompostaje: procesos, productos y aplicaciones. Ediciones MundiPrensa, Madrid, p 172

6. Castillo JM, Romero E, Nogales R (2013) Dynamics of microbial communities related to biochemical parameters during vermicomposting and maturation of agroindustrial lignocellulose wastes. Bioresour Technol 146:345-354. https://doi. org/10.1016/j.biortech.2013.07.093

7. Sangwan P, Kaushik CP, Garg VK (2010) Vermicomposting of sugar industry waste pressmud mixed with cow dung employing an epigeic earthworm Eisenia foetida. Waste Manag Res 28:71-75. https://doi.org/10.1177/0734242X09336315

8. Karmegam N, Vijayan P, Prakash M, John Paul JA (2019) Vermicomposting of paper industry sludge with cowdung and green manure plants using Eisenia fetida: a viable option for 
cleaner and enriched vermicompost production. J Clean Prod 228:718-728. https://doi.org/10.1016/j.jclepro.2019.04.313

9. GargVK Suthar S, Yadav A (2012) Management of food industry waste employing vermicomposting technology. Biores Technol 126:437-443. https://doi.org/10.1016/j.biortech.2011.11.116

10. Mahaly M, Senthilkumar AK, Arumugam S, Kaliyaperumal C, Karupannan N (2018) Vermicomposting of distillery sludge waste with tea leaf residues. Sustain Environ Res 28:223-227. https://doi.org/10.1016/j.serj.2018.02.002

11. Singh J, Kaur A, Vig AP, Rup PJ (2010) Role of Eisenia fetida in rapid recycling of nutrients from bio sludge of beverage industry. Ecotox Environ Saf 73:430-435. https://doi.org/10.1016/j. ecoenv.2009.08.019

12. Malafaia G, da Costa Estrela D, Guimarães ATB, de Araújo FG, Leandro WM, de Lima Rodrigues AS (2015) Vermicomposting of different types of tanning sludge liming and primary mixed with cattle dung. Ecol Eng 85:301-306. https://doi.org/10.1016/j. ecoleng.2015.10.010

13. Melgar R, Benítez E, Nogales R (2009) Bioconversion of wastes from olive oil industries using the epigeic earthworm Eisenia andrei. J Environ Sci Heal B 44:488-495. https://doi. org/10.1080/03601230902935444

14. Domínguez J, Martínez-Cordeiro H, Alvarez M, Lores M (2014) Vermicomposting grape marc yields high quality organic biofertilizer and bioactive polyphenols. Waste Manag Res 32:12351240. https://doi.org/10.1177/0734242X14555805

15. Bath SA, Singh J, Vig AP (2018) Earthworms as organic waste managers and biofertilizer producers. Waste Biomass Valor 9:1073-1086. https://doi.org/10.1007/s12649-017-9899-8

16. Fernández-Gómez MJ, Nogales R, Insam H, Romero E, Goberna $M$ (2010) Continuous-feeding vermicomposting as a recycling management method to revalue tomato-fruit wastes from greenhouse crops. Waste Manag 30:2461-2468. https://doi. org/10.1016/j.wasman.2010.07.005

17. Fernández-Gómez MJ, Romero E, Nogales R (2010) Feasibility of vermicomposting for vegetable greenhouse waste recycling. Bioresour Technol 101:9654-9660. https://doi.org/10.1016/j. biortech.2010.07.109

18. Fernández-Gómez $M$, Nogales R, Plante R, Plaza C, Fernández JM (2015) Application of a set of complementary techniques to evaluate the effect of varying the waste proportion on humic acids produced by vermicomposting. Waste Manag 35:81-88. https://doi.org/10.1016/j.wasman.2014.09.022

19. Ceccanti B, Masciandaro G, Macci C (2007) Pyrolysis-gas chromatography to evaluate the organic matter quality of a mulched soil. Soil Till Res 97:71-78. https://doi.org/10.1016/j. still.2007.08.011

20. Aranda V, Macci C, Peruzzi E, Masciandaro G (2015) Biochemical activity and chemical-structural properties of soil organic matter after 17 years of amendments with olive-mill pomace co-compost. J Environ Manag 147:278-285. https://doi.org/10.1016/j. jenvman.2014.08.024

21. Sims JR, Haby VA (1971) Simplified colorimetric determination of soil organic matter. Soil Sci 112:137-141. https://doi. org/10.1097/00010694-197108000-00007

22. Senesi N (1989) Composted materials as organic fertilizers. Sci Total Environ 81(82):521-542. https://doi.org/10.1016/00489697(89)90161-7

23. Williams S (1984) Official methods of analysis of the association of official analytical chemists, 14th edn. Association of Official Analytical Chemists, Arlington

24. Goering $H$, Van Soest $P$ (1970) Forage ceber analysis (apparatus reagents procedure and some applications). Agriculture handbook. USDA-ARS, Washington, pp 1-20

25. Khazaal K, Boza J, Orskov ER (1994) Assessment of phenolics-related antinutritive effects in Mediterranean browse: a comparison between the use of the in vitro gas production technique with or without polyvinilpolypyrrolidone or nylon bag. Anim Feed Sci Technol 49:133-149. https://doi. org/10.1016/0377-8401(94)90087-6

26. García C, Hernández MT, Costa F (1997) Potential use of dehydrogenase activity as an index of microbial activity in degraded soils. Commun Soil Sci Plan 28:123-134. https://doi. org/10.1080/00103629709369777

27. Nannipieri P, Ceccanti B, Conti C, Bianchi D (1982) Hydrolases extracted from soil: their properties and activities. Soil Biol Biochem 14:257-263. https://doi.org/10.1016/00380717(82)90035-9

28. Tabatabai MA (1982) Soil enzymes. In: Page AL, Miller EM, Keene DR (eds) Methods of soil analysis, part 2, Chemical and microbiological properties. ASA, SSSA, Madison, pp 907-943

29. Zucconi F, Pera A, Forte M, De Bertoldi M (1981) Evaluating toxicity of immature compost. Biocycle 22:54-527

30. Fernández-Gómez MJ, Diaz-Raviña $M$, Romero $E$, Nogales $R$ (2013) Recycling of environmentally problematic plant wastes generated from greenhouse tomato crops through vermicomposting. Int J Environ Sci Technol 10:697-708. https://doi. org/10.1007/s13762-013-0239-7

31. Benitez E, Sainz H, Melgar R, Nogales R (2002) Vermicomposting of a lignocellulosic by-product from olive oil industry: a pilot scale study. Waste Manag Res 20:134-142. https://doi. org/10.1177/0734242X0202000205

32. Borges YV, Alves L, Bianchi I, Espíndola JC, De Oliveira JM, Radetski CM, Somensi CA (2017) Optimization of animal manure vermicomposting based on biomass production of earthworms and higher plants. J Environ Sci Heal B 52:791795. https://doi.org/10.1080/03601234.2017.1356162

33. Garcia-Sanchez M, Taušnerová $H$, Hanc A, Tlustoš P (2017) Stabilization of different starting materials through vermicomposting in a continuous-feeding system: changes in chemical and biological parameters. Waste Manag 62:33-42. https:// doi.org/10.1016/j.wasman.2017.02.008

34. Parthasarathi K, Ranganathan LS (1999) Longevity of microbial and enzyme activity and their influence on NPK content in pressmud vermicasts. Eur J Soil Biol 35:107-113. https://doi. org/10.1016/S1164-5563(00)00114-X

35. Benitez E, Nogales R, Elvira C, Masciandaro G, Ceccanti B (1999) Enzyme activities as indicators of the stabilization of sewage sludges composting with Eisenia foetida. Bioresour Technol 67:297-303. https://doi.org/10.1016/S0960-8524(98)00117-5

36. Nannipieri $P$, Kandeler E, Ruggiero P (2002) Enzyme activities and microbiological and biochemical processes in soils. In: Burns RG, Dick RP (eds) Enzymes in the environment activity, ecology, and application. Dekker Marcel, New York, pp 1-33

37. Berlin A, Balakshin M, Gilkes N, Kadla J, Maximenko V, Kubo S, Saddler J (2006) Inhibition of cellulase, xylanase and $\beta$-glucosidase activities by softwood lignin preparations. J Biotechnol 125:198-209. https://doi.org/10.1016/j.jbiot ec.2006.02.021

38. Cunha-Queda AC, Ribeiro HM, Ramos A, Cabral F (2007) Study of biochemical and microbiological parameters during composting of pine and eucalyptus bark. Bioresour Technol 98:3213-3220. https://doi.org/10.1016/j.biortech.2006.07.006

39. Dick WA, Tabatabai MA (1993) Significance and potential uses of soil enzymes. In: Metting FB (ed) Soil microbial ecology application in agricultural and environment management. Marcel Dekker, New York, pp 95-125

40. Satchell JE, Martin K (1983) Phosphatase activity in earthworm faeces. Soil Biol Biochem 16:191-194. https://doi. org/10.1016/0038-0717(84)90111-1 
41. Macci C, Masciandaro G, Ceccant B (2010) Vermicomposting of olive oil mill wastewaters. Waste Manag Res 28:738-747. https ://doi.org/10.1177/0734242X09345278

42. Fernández-Gómez MJ, Romero E, Cifuentes C, Nogales R (2012) Hydrolases activities of extracted humic substances during vermicomposting of damaged tomatoes in a continuous feeding system. In: Trasar-Cepeda C, Rad C, Hernandez T, Garcia C, Gonzalez-Carcedo $S$ (eds) Soil enzymology in the recycling of organic wastes and environmental restoration. Environmental science and engineering series. Springer, Heidelberg, pp 299-309

43. Castaldi P, Garau G, Melis P (2008) Maturity assessment of compost from municipal solid waste through the study of enzyme activities and water-soluble fractions. Waste Manag 28:534-540. https://doi.org/10.1016/j.wasman.2007.02.002

44. Pramanik P, Ghosh GK, Ghosal PK, Banik P (2007) Changes in organic-C, N, P and $\mathrm{K}$ and enzyme activities in vermicomposts of biodegradable organic wastes under liming and microbial inoculants. Bioresour Technol 98:2485-2494. https://doi. org/10.1016/j.biortech.2006.09.017

45. Kumar JIN, Soni H, Kumar RN, Patil N (2010) Growth and reproduction of Eisenia foetida in various industry waste sludge during vermicomposting: a laboratory investigation. Int J Environ Waste Manag 5:379-391. https://doi.org/10.1504/IJEWM .2010 .032015

46. Huang K, Xia H, Cui G, Li F (2017) Effects of earthworms on nitrification and ammonia oxidizers in vermicomposting systems for recycling of fruit and vegetable wastes. Sci Total Environ 578:337-345. https://doi.org/10.1016/j.scitotenv.2016.10.172

47. Lv B, Xing M, Yang J (2016) Speciation and transformation of heavy metals during vermicomposting of animal manure. Bioresour Technol 209:397-401. https://doi.org/10.1016/j.biort ech.2016.03.015

48. Zhi-wei S, Tao S, Wen-jing D, Jing W (2019) Investigation of rice straw and kitchen waste degradation through vermicomposting. J Environ Manag 243:269-272. https://doi.org/10.1016/j. jenvman.2019.04.126

49. Bath SA, Singh J, Vig AP (2014) Genotoxic assessment and optimization of pressmud with the help of exotic earthworm Eisenia fetida. Environ Sci Poll Res 21:8112-8123. https://doi. org/10.1007/s11356-014-2758-2

50. European Union (2008) Commission Regulation (EC) No $889 / 2008$ of 5 September 2008 laying down detailed rules for the implementation of Council Regulation (EC) No 834/2007 on organic production and labelling of organic products with regard to organic production, labelling and control

51. Romero E, Plaza C, Senesi N, Nogales R, Polo A (2007) Humic acid-like fractions in raw and vermicomposted winery and distillery wastes. Geoderma 139:397-406. https://doi.org/10.1016/j. geoderma.2007.03.009

52. Zhang BG, Li GT, Shen TS, Wang JK, Sun Z (2000) Changes in microbial biomass $\mathrm{C}, \mathrm{N}$ and $\mathrm{P}$ and enzyme activities in soil incubated with the earthworms Metaphire guillelmi or Eisenia fetida. Soil Biol Biochem 32:2055-2062. https://doi.org/10.1016/S0038 $-0717(00) 00111-5$

53. Senesi N, Plaza C (2007) Role of humification processes in recycling organic wastes of various nature and sources as soil amendments. Clean 35:26-41. https://doi.org/10.1002/ clen.200600018

54. Masciandaro G, Ceccanti $B$ (1999) Assessing soil quality in different agro-ecosystems through biochemical and chemico-structural properties of humic substances. Soil Till Res 51:129-137. https://doi.org/10.1016/S0167-1987(99)00056-2

55. Stevenson FJ (1994) Humus chemistry. Genesis, composition, reactions, 2nd edn. Wiley, Toronto

56. Bondi G, Peruzzi E, Macci C, Masciandaro G, Pistoia A (2015) Changes in soil organic matter associated with pig rearing: influence of stocking densities and land gradient on forest soils in central Italy. Agric Ecosyst Environ 211:32-42. https:// doi.org/10.1016/j.agee.2015.05.003

57. Hernandez T, Masciandaro G, Moreno JL, Garcia C (2006) Changes in organic matter composition during composting of two digested sewage sludges. Waste Manag 26:1370-1376. https://doi.org/10.1016/j.wasman.2005.10.006

58. Masciandaro G, Ceccanti B, Garcia C (2000) "In situ" vermicomposting of biological sludges and impacts on soil quality. Soil Biol Biochem 32:1015-1024. https://doi.org/10.1016/S0038 $-0717(00) 00011-0$

Publisher's Note Springer Nature remains neutral with regard to jurisdictional claims in published maps and institutional affiliations. 